\title{
Working While in School: \\ Analysis of Aviation Students and Employment
}

\author{
Elizabeth Bjerke and James Higgins \\ University of North Dakota
}

\begin{abstract}
College costs are rising faster than inflation; when coupled with rising flight training costs, students are paying a high price for their aviation education. This study analyzed the effect that working has on an aviation student. A survey of aviation students $(\mathrm{n}=793)$ suggests that by working more than 10 hours a week, a student's GPA is likely to decrease. The study also revealed differences in the amount of time that students work when compared to year in school and receipt of financial aid. No variance was found between the different aviation majors and the amount of work reported. Students, faculty and administrators in aviation programs need to understand the overall effects of students' working while pursuing an aviation degree.
\end{abstract}

\section{INTRODUCTION}

The cost of a college degree is on the rise. Over the last five years the average increase in tuition charged at a public four-year institution rose 51\% (The College Board, 2007). A recent report published by the Department of Education cited cost and affordability of higher education as a rising concern and notes "the seemingly inexorable increase in college costs, which have outpaced inflation for the past two decades and have made affordability an ever-growing worry for students, families, and policymakers" (Commission on the Future of Higher Education, 2007, P. 2). When the cost of tuition is coupled with other student fees such as flight training at an aviation college, the effect is exacerbated; and it is the students who have to bear the burden.

Most flight schools charge an additional fee for flight training. Depending on the certificates and ratings achieved the cost can range from an additional $\$ 20,000$ to as much as $\$ 60,000$ above and beyond the typical costs for attending college. These fees are on the rise due to several factors which include the price of aviation-grade fuel being at a record high, increased insurance premiums, and the need to retain qualified flight instructors with corresponding higher wages (Decker, 2007).

The ability to pay for these rising costs becomes an area of concern for students and their families. Many students seek employment while in school to help offset the cost of their education. Does this outside work come with its own cost affecting student success while at college?

\section{REVIEW OF THE LITERATURE}

The National Center for Education Statistics' (NCES) report Postsecondary Financing Strategies: How Undergraduates Combine Work, Borrowing, and Attendance (1998), states that nearly three out of four students work while attending college. The act of working while attending college has both positive and negative results for students.

The obvious positive impact of working while in school is to make money to help pay for college expenses. King and Bannon (2002) found that nearly $84 \%$ of working students identify themselves as working to help pay for college expenses. Research (King \& Bannon, 2002; Kulm \& Cramer, 2006; NCES, 1998) also suggests that working part-time (less than 20 hours a week) has a positive impact on student persistence.

The negative aspects of working while in college manifest themselves primarily in academic achievement and persistence to complete a degree. King and Bannon (2002) found that students working more than 25 hours a week were twice as likely to report that work had a negative effect on their academic experience. It was found that too much work limited course offerings, class choice, and negatively impacted the student's grades (King \& Bannon, 2002). Similarly, Svanum and Bigatti (2006) found that the more a student 
worked, the less effort was put into the course, thus resulting in a lower academic grade. Kulm and Cramer (2006) found that students who were employed while at college were less likely to engage in extra-curricular activities.

Students engaged in a flight related major have the additional financial burden of flight costs added to their overall college expenses. Beckman and Barber (2007) found that financial constraints were the leading cause for students transferring out of a professional flight focused degree program. This same study also revealed no significant difference existed in the average number of hours worked by a student in the professional flight program than in any other aviation major (Beckman \& Barber, 2007). This study expands upon the research related to the effects of student employment in a high cost field of aviation by answering the following research questions:

1.) What percentage of students work while pursuing an aviation related degree?

2.) Does this vary by year in school, specific aviation major sought, and receipt of financial aid?

3.) What effect does working have on academic achievement and extracurricular involvement?

\section{METHODOLOGY}

\section{Participants}

During the 2007-2008 academic year a survey was administered to 793 college students attending a four-year public institution and majoring in an aviation related degree program. The institution offers six different majors in aviation including: Professional Flight, Air Traffic Control, Flight Education, Aviation Systems Management, Airport Management and Aviation Management.

The subjects were chosen based upon their enrollment in aviation classes. All flight classes and certain "gateway" classes within the aviation department were selected for survey participation. The "gateway" classes were classes where the greatest department-wide permeation could be achieved while restricting subject overlap.
Table 1. Selected Demographic Data

Demographic

Year in School

Major

GPA

Work status

Hours worked per week

Financial Aid

Materials

The survey was constructed by a committee of individuals who had a diverse set of subject matter expertise, including those with domain relevant experience and those with survey building experience and training. The resultant survey was administered in several sections. One section recorded demographic information, including those areas listed in Table 1. The survey was approved by the institution's review board since it involved the questioning of human subjects.

Students were given the survey via an online survey tool. Each student was able to access the website through their leased laptop from the university. The website required no extra software installation and was accessible through any type of web browser.

\section{Procedures}

A research assistant visited each selected classroom to recruit student participants, answer any questions, and direct students to the survey website. The classroom visit and subsequent survey took around 20 minutes to complete. In order to ensure anonymity, each participant selected an individually-printed random number from a box. The random number was later matched to an official roster of numbers generated by computer. This procedure ensured that each participant was indeed a student while maintaining anonymity. All survey respondents who did not enter a correct random number were stricken from the dataset (31 surveys). 


\section{RESULTS}

Only sixty-percent of the survey respondents reported they worked while in school; this result is $15 \%$ less than the nationally reported statistics (NCES, 1998). Several additional analyses were conducted to determine whether the percentages of students who worked varied with the following factors: year in school, aviation major, financial aid and extra-curricular activities. Table 2 lists the findings from these analyses.

Table 2. Chi-square Analysis for Hours Worked

\begin{tabular}{cccc}
\hline Variable & $\mathrm{n}$ & $\mathrm{df}$ & $\chi^{2}$ \\
\hline Year in School & 791 & 15 & $153.13^{* *}$ \\
Aviation major & 672 & 25 & 26.29 \\
Financial aid & 790 & 5 & $27.55^{* *}$ \\
Extra-curricular & 789 & 5 & $12.61^{*}$ \\
\hline
\end{tabular}

$* p<.05 . * * p<.01$

The statistical analysis revealed that three of the four variables had significant differences when compared against the hours students worked; these variables were: year in school, receipt of financial aid, and involvement in student organizations (extra-curricular activities).

The year in school had a significant effect on the hours worked by students. The chisquare analysis showed that senior students reported working more hours than expected with an expected count of 35.6 at 21-30 hours and an observed count of 54. The expected count at 3140 hours for a senior was 13.5 with an observed of 24. On the other end of the spectrum were the freshmen who reported working less than expected (11-20 hours with expected 49.2 and observed 25; 21-30 hours expected 29.2, observed 5).

There were a significantly higher percentage of students who neither worked nor received financial aid $(14.05 \%$ observed versus $10.76 \%$ expected). Finally, there was a greater likelihood of finding students who worked and were also involved in student organizations. Kulm and Cramer (2006) found that students who worked were less likely to be involved with extra-curricular than non-working students. The finding from this study contradicts this previous research.

The one variable that displayed no significant differences in regard to hours worked was declared aviation major. Similar to other research (Beckman \& Barber, 2007), it was found that no significant difference existed in the hours students worked for different aviation majors. Table 3 indicates the hours worked by major where there were at least five students reporting in the hour category.

Hours worked by students were divided into six separate groups (see Table 4). Mean Grade Point Averages (GPAs) grouped by hours worked per week are also reported in Table 4. A one-way Analysis of Variance (ANOVA) (see Table 5) revealed a significant difference between groups $F(5,588)=3.35, p=.005$. Post hoc analysis using Tukey's HSD revealed significant differences between those students who work between one to ten hours per week (M $=3.43, \mathrm{SD}=.39$ ) and those working between eleven to twenty and twenty-one to thirty hours $(\mathrm{M}=3.32, \mathrm{SD}=.39$ and $\mathrm{M}=3.25, \mathrm{SD}=.40$, respectively).

The results of this survey indicate that students who work between 1-10 hours a week have a significantly higher GPA than the other groups. This finding coincides with previous research (King \& Brannon, 2002) stating that part-time work can create a positive impact on academic performance, and that too much work can have negative effect on performance. 
Table 3. Percentage of Hours Worked by Major (With cells greater than $n=5$ )

\begin{tabular}{ccccccc}
\hline & \multicolumn{7}{c}{ Hours worked per week } \\
\cline { 2 - 6 } Major & 0 & $1-10$ & $11-20$ & $21-30$ & $31-40$ & $40+$ \\
\hline Professional Flight & 35.8 & 15.8 & 25.1 & 15.5 & 5.0 & 2.8 \\
Helicopter & 52.6 & 14.0 & 15.8 & 12.3 & $*$ & $*$ \\
Air Traffic Control & 39.7 & 9.3 & 23.8 & 16.6 & 8.6 & $*$ \\
Aviation Management & 55.8 & $*$ & 23.3 & $*$ & $*$ & $*$ \\
Airport Management & 33.3 & $*$ & $*$ & $*$ & $*$ & $*$ \\
\hline$* \mathrm{n}<5$ Note. All cells in Aircraft Systems Management major were less than 5 & & \\
\hline
\end{tabular}

Table 4. Mean Grade Point Averages based upon Hours Worked

\begin{tabular}{cccc}
\hline Hours worked per week & Mean GPA & Standard deviation & Sample size \\
\hline Zero (did not work) & 3.33 & .41 & 179 \\
$1-10$ & 3.43 & .39 & 87 \\
$11-20$ & 3.32 & .39 & 165 \\
$21-30$ & 3.25 & .40 & 105 \\
$31-40$ & 3.20 & .37 & 41 \\
40 or more & 3.17 & .42 & 17 \\
\hline
\end{tabular}

Table 5. Analysis of Variance for Hours Worked and Grade Point Average

\begin{tabular}{ccccc}
\hline & Sum of Squares & df & Mean Square & F \\
\hline Between Groups & 2.65 & 5 & .531 & $3.35^{*}$ \\
Within Groups & 93.24 & 588 & .159 & \\
Total & 95.89 & 593 & & \\
\hline
\end{tabular}

$* \mathrm{p}<.01$

\section{RECOMMENDATIONS AND CONCLUSIONS}

The findings have numerous implications for students, faculty and administrators involved with collegiate aviation programs. Due to rising costs, some of today's students need to work to afford attending college. Despite the need to work, students should be made aware of what effect it may have on their academic achievement and ultimately their ability to persist in school. When choosing a job, students should seek out employers who are sensitive to student needs. Students should also seek out alternative methods of funding such as scholarships, which can help alleviate some of the financial pressure placed on them.

Faculty should understand and be made aware that many students sitting in their classes are putting in over 50 hour weeks when combining school, work and flying. If the faculty have a voice in disseminating 
departmental scholarships or other merit-based awards, academic achievement as represented by GPA should not be the only consideration. A student working full-time will more likely have a lower GPA as a result. When advising aviation students, faculty should encourage the student to seek employment in an area that will help them succeed in their career aspirations.

Aviation department administrators need to understand that students are sacrificing time and energy that could be devoted to study by working to afford their education. Anything that can be done to help curb the costs students incur while pursuing an aviation degree should be analyzed. Administrators should also make it a priority to secure more aviation student scholarships that can be awarded to help offset the cost of college. While procuring additional monies for scholarships, information on the rising costs to students, and the student's need to work, must be explained to potential benefactors.

This research revealed numerous other areas that are in need of further study. Although national research (NCES, 1998) reports that three out of four students work while attending college, this survey of strictly aviation students found that only three out of five students are employed during the academic year. Further research in this area could help determine if this is a specific institutional phenomena or if it holds true in most collegiate aviation programs.

This research unveiled many other questions that could be further studied by using either a quantitative or qualitative approach. Since aviation can be classified as a high cost program, why do fewer students work while attending school compared to the national data? Also, since flight is the most costly major, why is there no difference in hours worked between flight and non-flight aviation majors? Why do upperclassmen work more than freshman students? Why do working aviation students tend to participate more in extra-curricular activities?

Other areas that can be studied which branch off of the original research intent of this study, include a more detailed analysis of financial aid and scholarship programs in aviation education. Are aviation students leaving college with a significant amount of debt incurred through financial aid? What types of successful scholarship programs exist, and how is equitable distribution of the monies awarded in collegiate aviation programs?

A better understanding of students' financial sensitivity will ensure that programs provide the highest level of aviation education at the most reasonable cost to the students. In doing this, not only will our students graduate with the skills and knowledge needed to be successful in the aviation industry, they will have less financial pressures placed on them while attending school. 


\section{REFERENCES}

Beckman, W. S. \& Barber, P. M. (2007) Factors impacting student retention in a University professional pilot program. International Journal of Applied Aviation Studies, 7(2), 295-311.

Commission on the Future of Higher Education (2006). A test of leadership: Charting the future of U.S. higher education (ED-06-C0-0013). Washington, DC: Government Printing Office.

Decker, J. (2007, July 3). School's out for new pilots. Flight International, 172, 34-37.

King, T. \& Bannon, E. (2002). At what cost? The price that working students pay for a college education. The State PIRGs' Higher Education Project. Retrieved March 21, 2008, from http://www.pirg.org/highered/atwhatcost4_16_02.pdf.

Kulm, T. L. \& Cramer, S. (2006). The relationship of student employment to student role, family relationships, social interactions and persistence. College Student Journal, 40(4), 927-938.

National Center for Education Statistics. (1998). Postsecondary financing strategies: How undergraduates combine work, borrowing and attendance (NCES 98-088). Washington D.C: Government Printing Office.

Svanum, S. \& Bigatti, S. M. (2006). The influences of course effort and outside activities on grades in a college course. Journal of College Student Development, 47(5), 564-576.

The College Board. (2007). Trends in College Pricing. Washington, DC: The College Board. 